\title{
THE DEPLETION OF THE HUMAN RESOURCES POOL IN SOUTH AFRICA
}

$\mathrm{J}$ du Preez (Birmingham, UK)

The brain drain has become one of the dominant realities within the South African economy. The official emigration statistics from South African sources inadvertently minimizes the seriousness of the threat, but emigration figures received from foreign countries are indicative of the size of the problem.

Emigration, however, is not the only cause for the depletion of the human resource pool. Internal migration, pseudo-emigration and the influx of unskilled workers also negatively effect the composition of the human resource provision in the country. Murder, HIVIAIDS and related diseases severely impact industry and will increasingly contribute to the brain drain.

A radical reduction of the skilled work force and a dramatic shift in the composition of the human resource pool towards unskilled labour negatively impact on industry and inhibits South Africa's ability to compete effectively in an increasingly global market.

Keywords: brain drain, emigration, human resources pool, immigration, migration, psychological emigration

\section{INTRODUCTION}

A major brain drain is taking place in South Africa, negatively affecting the economy. There are a number of forces operational in the socio-economic environment that is detrimental to the skills pool in South Africa. This has resulted in a dramatic depletion of skilled and highly skilled workers from the country. The causes for this depletion need to be understood before strategic action can be taken.

\section{BRAIN DRAIN THROUGH MIGRATION}

"Migration across continents and regions has been a part of human existence for thousands of years as a result of humans exploring or fleeing their enemies or natural disasters" (Van Rooyen 2000:1).

Emigration refers to the departure from a home country to another with the intention of acquiring permanent residence there. Immigration into a country can be defined as a person moving from a foreign country with the intention of settling in the new country of destination. Migration can take place internally within a country with people moving from one area to another in search of better living conditions.

South Africa is experiencing a tremendous flux in the migration of workers from and into the economy, which is indicative of socio-economic instability. Five major migratory forces are affecting the composition of the human resource pool in South Africa.

\section{Brain drain through emigration}

From 1989 till 1992 on average 4500 people emigrated from South Africa yearly according to official statistics. From 1993 to 1999 the figure doubled on average (Simelane 1999:6-7). 
The number of people leaving South Africa each year, however, is at least double and could be triple the official numbers (Van Rooyen 2000:26-29). The main reason is not due to a government conspiracy, but rather a desire by emigrants to cut paper work when filling out forms at South African airports (e.g. tax clearance) and retaining a "psychological anchor" should they decide to come home (Mitchell 2002:Internet). For example a total of 3261 emigrants were processed by the Canadian embassy in Pretoria between 1994 and 1997, compared to the 1288 claimed by official South African sources. The Canadian statistics are almost three times as many as those from the South African source (Van Rooyen 2000:27). Research by the University of Cape Town's policy research unit says the brain drain of skilled professionals emigrating between 1989 and 1997 are almost four times more than the official figure of 11255 (Dickson 2002b:Internet).

Finance Minister Trevor Manual allows a travel allowance of close to R 500000 per family of two adults and two children over twelve. For the average family that amount covers their total savings and therefore does not necessitate them to emigrate officially. Many young people do not possess any significant amount of money and therefore official emigration is not relevant to their situation.

\section{Composition of the workforce leaving the country}

The composition of the workforce leaving the country is predominantly white (about 90 percent) and skilled or highly skilled (South African Emigration 2002a:Internet). "The white exodus, once a trickle, has turned into a steady stream and has the potential to become a flood. The departure of these emigrants has made and is making South Africa poorer in every conceivable way. It negatively affects the lives of all South Africans and, ultimately, together with unemployment and AIDS, endangers the survival of the South African state in the $21^{\text {st }}$ century" (Mitchell 2002:Internet).

Strict entry requirements apply to the popular emigration destinations (Britain, Australia, USA, New Zealand and Canada). In general these countries require high levels of education and advanced occupational skills (Van Rooyen 2000:62-68). For example, Canada has a point system. It requires an applicant to meet the minimum number of points (70) to obtain an immigrant visa. The point system is based on ten criteria, each with a different weight. These criteria are age, education, training, occupation, arranged employment (a job offer by a Canadian employer), work experience, language ability, demographic factor (predetermined by the government: e.g. placement of a doctor in a rural area), personal suitability, and relatives in Canada (Canadian Immigration 2002:Internet). As a result of this screening process predominantly skilled and highly skilled workers are leaving South Africa. More than half (about 54 percent on average per year since 1994) are from a professional background (doctor, engineer, accountant, and teacher/lecturer) or managerial/executive background (Van Rooyen 2000:36). IT specialists, semi-professionals and technically-skilled workers also leave "in droves" (Dickson 2002:1).

\section{The influx of unskilled immigrants}

The number of official immigrants since 1994 is predominantly unskilled. "Of the 3623 documented immigrants accepted into South Africa in the first half of 2002 (4 832 in 2001), 
367 were in professional, semi-professional and technical occupations - mostly in education - and 232 were in managerial, executive and administrative occupations. But a staggering 2956 (3879 in 2001) were categorised as not economically active - and 1982 of them were classed as spouses" (Dickson 2002b:Internet).

An even greater problem is the number of unskilled workers pouring in from the war and hunger zones across the South African borders in search of a better future. The Human Research Council already estimated in 2000 that the number of unskilled foreigners in the country were between 2,5 and 4,1 million (Van Rooyen 2000:20).

The Law of Gresham states "bad money drives out good money". Similarly, unskilled labour drives out skilled labour. The economic significance of this influx is that the ratio between skilled and unskilled workers in the workforce is deteriorating and placing increasing burdens on the country's economic resources pool, thereby enlarging the crime and violence potential.

This in turn leads to more skilled people leaving, which results in job losses for unskilled workers in a continuing downward cycle. According to the Central Bureau of Statistics ten unskilled workers loose their jobs for every skilled person leaving the economy (Business Day 2001:1).

\section{Brain drain though internal migration}

Due to the instability, crime, violence and work scarcity in the country, people are migrating to geographical areas that they perceive as either being safe or will offer them potential work or a better quality of life. In the 1990s thousands of whites from Gauteng made the Cape their home due to a perception that it is a safe haven away from a crime-torn Gauteng. Exact statistics are not known but it was reported that in 1996 alone 43 new pupils from Gauteng enrolled in the Gordon's Bay primary school while in other Cape Town schools the average was about fifteen (Rapport 1998:6).

During the last couple of years, however, Cape Town, that was once known as the Cape of Good Hope, has become the crime capital of the world and is now been given the following negative designations, namely "Cape of Storms, Cape of Lost Hope, Rape Town and Cape of Murder" (Van Rooyen 2000:14). This has caused many people to return to Gauteng and deterred many others to move.

Instability like these influences the composition and quality of the workforce in the different regions and contributes to an internal brain drain.

\section{Red tape inhibits the immigration of skilled workers}

Another factor contributing to the skills drain is that the Home Affairs Department, which controls immigration, has a bad reputation for putting major obstacles in the way of prospective skilled immigrants (Business Day 2001:1). 


\section{Brain drain through pseudo emigration}

A large sector of the white society has psychologically emigrated through a kind of "selfinduced emotional detachment from the realities of South Africa" or a purposeful withdrawal from many spheres of South African society. This could include abstaining from voting in elections, not reading newspapers, not watching SABC news, sending their children to private schools, not participating in sport or cultural events (Van Rooyen 2000:17-18). High walls, razor wires, electrified fences, walled in neighbourhoods, Doberman dogs and alarm systems are some of the defence mechanisms used to protect their private world from being destroyed by destructive forces operating in South Africa.

It can be concluded that the participation of such members in society can at best be described as half-hearted and uncommitted. Their contribution to the workplace will be apathetic rather than dynamic, doing what is expected rather than what is creatively needed. In a real way this contributes to a brain drain of committed action and dynamic strategising.

\section{BRAIN DRAIN THROUGH MURDER}

On average 25000 people are murdered each year in South Africa (South African Emigration 2002b:Internet). This has a major effect on service and production in the country. Some of the worst hit groups are farmers and the police force, with approximately 800 farmers killed between 1994 and 1999 and on average 400 members of the police force lose their lives each year (Van Rooyen: 2000:77,83). Their existence has become very precarious. Murder causes serious destabilisation of certain sectors of the economy, such as agriculture and results in a dramatic erosion of the general brain pool in South Africa. It costs an estimated R 250000 to replace a skilled labourer in South Africa (Maritz 2002:3).

\section{BRAIN DRAIN THROUGH HIV/AIDS AND RELATED ILLNESSES}

South Africa has the fastest growing HIV/AIDS pandemic in the world, with more people being infected with the virus than in any other country (Maritz 2002:3). HIV/AIDS is mainly found between two age groups: infants, and adults between the ages of 20 to 40 . The majority of workers in business organisations fall in the adult group, which under normal circumstances would be the most productive, healthy and vigorous members of the workforce. This pandemic differs from other diseases, such as Tuberculosis, because it affects people from all walks of life. The victims include very skilled people, such as managers, judges, advocates, doctors and engineers (Maritz 2002:34). The impact of HIV/AIDS on company productivity and profitability include factors as the following: worker absenteeism; employee turnover; loss of skills; retraining of the workforce; large contributions to health and life insurance, as well as the disruption of production (George \& Whiteside 2002:219 ;Maritz: 2002: 93-118).

HIV/AIDS is an increasingly dominant factor contributing to the brain drain in South Africa. 


\section{CLOSURE}

It is clear that a radical erosion of the skilled and highly skilled sector of the work force is taking place (Fraser 2002:4).. There is also a dramatic shift in the composition of the human resource pool towards unskilled labour. This has a negative impact on the industry and inhibits South Africa's ability to compete effectively in an increasingly global market

\section{BIBLIOGRAPHY}

BUSINESS DAY. 2001. Brain drain spreads the pain around, col. 1:1, February 23.

CANADIAN IMMIGRATION. 2003. Detailed information on the points system and other requirements for immigrating into Canada. (Internet: http://www.cic.gc.ca/english/applications/menu-outside.html.)

DICKSON P. 2002a. SA's best brains leave in droves. Pretoria News :1, October 16.

DICKSON P. 2002b. Brain drain claims thousands more. Cape Times. (Internet: http://www.solidarity.co.za/home/ content.asp?Parentid=23\&ID=791.)

FRASER J. 2002. Business helps with education of engineers: Aim is to reverse brain drain effects. Business Day :4, July 16.

GEORGE G \& WHITESIDE A. 2002. AIDS in the private sector. South African Health Review, 12:219.

MARITZ G 2002. Impacts of HIVIAIDS for business organisations: a strategic management approach. Johannesburg: RAU [M Com (Strategic Management dissertation).]

MITCHELL J. 2003. A news review in the Star about the white exodus out of SA. (Internet: http://www.SouthAfricanEmigration.com/reviews.htm;.)

RAPPORT. 1998. Gauteng leerlinge in Kaapse skole :6, Desember 6.

SIMELANE SE. 1999. Trend in international migration: migration among professionals, semi-professionals and miners in South Africa. 1970-1997, Statistics South Africa. 6-7:July 5.

SOUTH AFRICAN EMIGRATION. 2003. General statistics on the South African emigration.

(Internet: (a) http://www.SouthAfricanEmigration.com/did-you-know.htm, statistics on SA emigration;

Internet: (b) http://www.SouthAfricanEmigration.com/why emigrate.htm, explains why people leave SA.)

VAN ROOYEN J. 2000. The New Great Trek: The story of South Africa's white exodus. Pretoria: Unisa Press. 